\title{
ACE gene I/D polymorphism and severity of SARS-CoV-2 infection in hospitalized patients: a meta-analysis
}

\author{
Teodoro J. Oscanoa $\oplus^{1,2}$, Xavier Vidal $\odot^{3}$, Eliecer Coto $\oplus^{4-7}$, Roman Romero-Ortuno $\odot^{8,9}$ \\ 'Facultad de Medicina Humana, Universidad de San Martín de Porres, Lima, Perú \\ ${ }^{2}$ Facultad de Medicina, Universidad Nacional Mayor de San Marcos, Lima, Perú \\ ${ }^{3}$ Clinical Pharmacology Department, Vall d'Hebron Hospital, Barcelona, Spain \\ ${ }^{4}$ Genética Molecular, Hospital Universitario Central Asturias, Oviedo, Spain \\ ${ }^{5}$ Instituto de Investigación Sanitaria del Principado de Asturias, ISPA, Oviedo, Spain \\ ${ }^{6}$ Universidad de Oviedo, Oviedo, Spain \\ ${ }^{7}$ Red de Investigación Renal (REDINREN), Madrid, Spain \\ ${ }^{8}$ Discipline of Medical Gerontology, Mercer's Institute for Successful Ageing, St. James's Hospital, Dublin, Ireland \\ ${ }^{9}$ Global Brain Health Institute, Trinity College Dublin, Ireland
}

\begin{abstract}
Background: Hypertension and type 2 diabetes increase the risk of severe SARS-CoV-2 infection. On the other hand, homozygous ACE deletion polymorphism (DD) has been associated with these two diseases and risk of acute respiratory distress syndrome. The aim of the study was to conduct a meta-analysis of the association between ACE gene I/D polymorphism (DD, II and DI) and severity of SARS-CoV-2 infection in hospitalized patients.

Material and methods: We searched PubMed, EMBASE and Google Scholar for studies published between January 2020 and April 2021. We included case-control studies evaluating the association between $A C E I / D$ and severity of SARS-CoV-2 infection in hospitalized patients, were there was sufficient genotype or allele frequency data to calculate IRR (incidence rate ratio) and 95\% confidence intervals (CIs).

Results: Five studies were included (mean age 58.5 years and $61 \%$ men), combining to a total of 786 patients. Four studies were conducted in Caucasians. Overall, patients who had homozygous co-dominance genotype DD were at $47 \%$ higher risk of severe COVID-19 compared with II or ID (IRR: 1.47; 95\% CI: 1.15-1.89; p = 0.002). Conclusions: The ACE DD genotype may confer a greater risk of severe COVID-19 in hospitalized patients. Further studies including more diverse ethnic groups are necessary to fully establish this association.
\end{abstract}

Key words: ACE gene, I/D polymorphism; SARS-CoV-2, COVID-19; meta-analysis

Arterial Hypertens. 2021, vol. 25, no. 3, pages: 112-118

DOI: $10.5603 /$ AH.a2021.0018

\section{Introduction}

The renin-angiotensin system (RAS) has an important role in regulating vascular physiology, directly or indirectly influencing functions of the lung, heart, kidney, brain and the immune system [1]. Angiotensin-converting enzyme 1 (ACE1) converts angiotensin-1 (Ang-I) to angiotensin-2 (Ang-II); Ang-II medi-

\footnotetext{
Address for correspondence: Teodoro J. Oscanoa, Universidad de San Martín de Porres, Facultad de Medicina Humana, Centro de Investigación de Seguridad de Medicamentos, Alameda del Corregidor 1531, La Molina 15024. Lima, Perú; Hospital Almenara ESSALUD. Lima-13. Perú; Universidad Nacional Mayor de San Marcos, Facultad de Medicina, Lima, Perú, tel: (511) 942 820820; e-mail: tjoscanoae@gmail.com
}

This article is available in open access under Creative Common Attribution-Non-Commercial-No Derivatives 4.0 International (CC BY-NC-ND 4.0) license, allowing to download articles and share them with others as long as they credit the authors and the publisher, but without permission to change them in any way or use them commercially 
ates its effects through activation of AT-1 and AT-2 receptors. On the other hand, angiotensin-converting enzyme 2 (ACE2) converts the potent vasoconstrictor angiotensin-II (Ang-II) into the vasodilator Ang1-7, which is crucial in controlling the local tissue homeostasis due to its anti-inflammatory, anti-coagulant, anti-proliferative and anti-fibrotic activity [2]. The normal physiological balance of RAS is based on the balance between the activity of the two axes or antagonist enzymes ACE1 and ACE2; that is, a local vasoconstrictor/proliferative axis (ACE1/Ang-II/AT1 receptor), versus vasodilator/anti-proliferative axis (ACE2/Ang1-7/MAS receptor) [3].

The entry mechanism of SARS-CoV-2 into human cells is by binding its spike protein to the membrane receptor ACE2 and interacting with the transmembrane serine protease 2 (TMPRSS2) [4]. It has been postulated that during SARS-CoV-2 infection, a reduction in ACE2 expression/activity and, consequently, the balance between the two antagonist enzymes ACE1 and ACE2 is broken, in favor of the former; that is, the axis with vasoconstrictor/proliferative effects (ACE1/Ang-II/AT1 receptor) predominates, with deleterious action to organ functions including in the lung, kidney and heart [5]. Loss of ACE2 expression in mutant mice is associated with worse lung function and characterized by increases in vascular permeability, lung edema and neutrophil accumulation [6].

The ACE1 gene maps on chromosome 17 (locus 17q23.3) and the ACE2 gene on chromosome $X$ (locus Xp22.22) [3]. ACE1 has an insertion/deletion polymorphism that is characterized by an insertion (allele I) or deletion (allele D) of a 287 base pair marker in intron 16 that results in three different genotypes (DD and II homozygotes or ID heterozygotes) [3]. The DD genotype has been found to show the highest serum/tissue ACE1 activity, probably because it maintains the two active sites favoring Ang-I to Ang-II formation; on the other hand, the ID genotype shows intermediate levels, and the II genotype the lowest, probably because it only has one of the two enzyme active sites in the ACE1 I-allele. [7Five ecological studies have recently been published on the association of ACE-1 I/D polymorphism with COVID-19 incidence and mortality. Ecological studies consist of establishing a relationship between the geographical variation of the I/D polymorphism of the ACE1 gene, with the mortality and severity of COVID-19 reported by organizations such as the Center for Systems Science and Engineering at Johns Hopkins University (https: //coronavirus.jhu.edu/map.html). Four ecological studies found that the country level frequency of the $\mathrm{D}$ allele was associated with increased
COVID-19 incidence and mortality [8-11]. One study considered that this relationship may be regarded as a confounder in the spread of COVID-19 and the outcome of the infection [12].

The present systematic study aimed to evaluate the association between ACE Gene I/D polymorphism and severity of SARS-CoV-2 infection in hospitalized patients.

\section{Material and methods}

This study was conducted following the guidelines of the Preferred Reporting Items for Systematic Reviews and Meta-analyses (PRISMA) [13].

\section{Search strategy}

Two independent reviewers performed a systematic review in PubMed, EMBASE, and Google Scholar for studies published between January 2020 and April 2021. The terms used were " $A C E \mathrm{I} / \mathrm{D}$ ", "polymorphism", "COVID-19", "SARS-CoV-2", "angiotensin converting enzyme insertion-deletion" and "COVID-19" as medical subject headings.

\section{Eligibility criteria}

The inclusion criteria were as follows: (i) case-control study design evaluating the association between $A C E$ $\mathrm{I} / \mathrm{D}$ and severity of SARS-CoV-2 infection in hospitalized patients and (ii) sufficient genotype or allele frequency data to allow calculation of odds ratios (ORs) and 95\% confidence intervals (CIs). The exclusion criteria were as follows: a) studies without controls; b) studies with genotype or allele frequencies that were unusable or absent; c) articles that did not cover the polymorphism or disease in question, and d) reviews.

\section{Data extraction and data distribution}

The following data were extracted from each study: authors, study location, year of publication, study design, number of participants, sex, age at baseline, outcome definition (COVID-19 severity and mortality), country of origin, ethnicity, comorbidities, sample sizes and genotype data. Data distribution was assessed with the Shapiro- Wilks test [14]. The use of the mean \pm standard deviation indicated a normal data distribution; otherwise, the choice of descriptive was the median with interquartile range.

\section{Quality assessment and Hardy-Weinberg Equilibrium (HWE)}

The methodological quality of observational studies (cohort and case control studies) was appraised 
according to the Clark-Baudouin scale [15]. Two investigators evaluated the quality of the studies independently. Conflicting results were resolved by discussion and involvement of a third reviewer if necessary. The Hardy-Weinberg Equilibrium (HWE) was assessed using the application in https://ihg.gsf. de/cgi-bin/hw/hwa1.pl.

\section{Outcome definition}

High severity was defined as a composite of mortality and/or any of the following indicators: need for mechanical ventilation, critical care, severe pneumonia or pulmonary embolism. Survivors in the absence of any high severity indicators were considered to have disease without high severity.

\section{Data synthesis}

We conducted a meta-analysis between the $A C E$ I/D polymorphism and the risk of severity/mortality composite outcome, with allelic (I versus $\mathrm{D}$ allele), dominant (I/I versus $\mathrm{I} / \mathrm{D}+\mathrm{D} / \mathrm{D})$, and recessive $(\mathrm{I} / \mathrm{I}+\mathrm{I} / \mathrm{D}$ versus $\mathrm{D} / \mathrm{D})$ models. The overall estimates in the pooled analysis were obtained using Stata 13 software (Stata Corp LP, College Station, TX). The pooled odds ratios (OR) were calculated using DerSimonian-Laird random-effects models [16] with 95\% confidence intervals (CI) to measure the strength of the association. $\mathrm{I}^{2}$ indicates the percentage variance in the pooled IRR (incidence rate ratio) that can be attributed to heterogeneity.

\section{Results}

After screening 308 citations, 5 case-control studies were included, with a total sample of 786 participants. Overall, mean (SD) age was 58.5 (6.26) years and $61 \%$ were men. The characteristics of included studies are summarized in Table 1 . The studies were from Spain [17], India [18], Italy [19] and Turkey $[20,21]$. Ethnicity was Caucasian in 4 studies, with the fourth study including patients of Indian ethnicity. Table 2 describes the distribution of the ACE polymorphisms in the included studies.In all the included studies the outcome reported was severity, and none included mortality. The mean of Clark-Baudouin score was 6.4 (6-8).

Patients who had homozygous co-dominance genotype DD were at $47 \%$ higher risk of severe COVID-19 compared with II or ID (IRR: 1.47; 95\% CI: $1.15-1.89 ; \mathrm{p}=0.002)$ (Fig. 2). We did not detect significant heterogeneity $\left(\mathrm{I}^{2}=9.4 \%\right)$. In the II versus $\mathrm{DD}+\mathrm{ID}$ model, a protective IRR of 0.72 (95\% CI: 0.54-0.97; $\left.\mathrm{p}=0.028 ; \mathrm{I}^{2}=0 \%\right)$ was obtained. In model $\mathrm{DD}$ vs II $+\mathrm{ID}$, when the study of Gunal et al. was excluded (because, Hardy-Weinberg Equilibrium > 0.05), the value of IRR was $1.48 ; 95 \%$ CI: $1.10-1.97(p=0.009)$.

\section{Discussion}

The present study suggests that the DD genotype may confer an increased risk of severe COVID-19.

Table 1. Characteristics of the studies included in the meta-analysis

\begin{tabular}{|c|c|c|c|c|c|c|c|c|c|c|c|c|}
\hline \multirow{2}{*}{ Author } & \multirow{2}{*}{ Country } & \multirow{2}{*}{ Ethnicity } & \multirow{2}{*}{ Outcome } & \multicolumn{2}{|c|}{ Mean age } & \multicolumn{2}{|c|}{ Male sex (\%) } & \multicolumn{2}{|c|}{ Hypertension } & \multicolumn{2}{|c|}{$\begin{array}{c}\text { Diabetes mellitus } \\
\text { type } 2\end{array}$} & \multirow{2}{*}{ CBS } \\
\hline & & & & Severe & $\begin{array}{l}\text { Non- } \\
\text {-severe }\end{array}$ & Severe & $\begin{array}{l}\text { Non- } \\
\text {-severe }\end{array}$ & Severe & $\begin{array}{l}\text { Non- } \\
\text {-severe }\end{array}$ & Severe & $\begin{array}{c}\text { Non- } \\
\text {-severe }\end{array}$ & \\
\hline $\begin{array}{l}\text { Gómez } \\
\text { et al. } \\
\text { (2021) }\end{array}$ & Spain & Caucasian & $\begin{array}{c}\text { Severity } \\
\text { (need of critical } \\
\text { care) }\end{array}$ & 65.76 & 64.56 & $\begin{array}{c}53 \\
(79)\end{array}$ & $\begin{array}{c}72 \\
(53)\end{array}$ & $\begin{array}{c}41 \\
(61)\end{array}$ & $\begin{array}{c}56 \\
(41)\end{array}$ & $\begin{array}{c}15 \\
(22)\end{array}$ & $\begin{array}{c}21 \\
(15)\end{array}$ & 6 \\
\hline $\begin{array}{l}\text { Celik } \\
\text { et al. } \\
\text { (2021) }\end{array}$ & Turkey & Caucasian & $\begin{array}{c}\text { Severity } \\
\text { (pneumonia } \\
\text { on chest CT/ } \\
\text { /mechanical } \\
\text { ventilation) }\end{array}$ & 87.47 & 44.6 & $\begin{array}{c}77 \\
(49.7)\end{array}$ & $\begin{array}{c}78 \\
(50.3)\end{array}$ & NR & NR & NR & NR & 6 \\
\hline $\begin{array}{l}\text { Verma } \\
\text { et al. } \\
\text { (2020) }\end{array}$ & India & Hindu & $\begin{array}{c}\text { Severity } \\
\text { (pneumonia) }\end{array}$ & NR & NR & $\begin{array}{c}73 \\
(60.8)\end{array}$ & $\begin{array}{c}97 \\
(65.1)\end{array}$ & $\begin{array}{c}20 \\
(16.7)\end{array}$ & $\begin{array}{c}7 \\
(4.7)\end{array}$ & $34(28.3)$ & $\begin{array}{c}13 \\
(87)\end{array}$ & 6 \\
\hline $\begin{array}{l}\text { Calabrese } \\
\text { et al. } \\
\text { (2021) }\end{array}$ & Italy & Caucasian & $\begin{array}{l}\text { Severity } \\
\text { (pulmonary } \\
\text { embolism) }\end{array}$ & 62 & 57 & $\begin{array}{c}19 \\
(76)\end{array}$ & $\begin{array}{c}29 \\
(63.8)\end{array}$ & $\begin{array}{c}13 \\
(52)\end{array}$ & $\begin{array}{c}21 \\
(48)\end{array}$ & $\begin{array}{c}3 \\
(12)\end{array}$ & $\begin{array}{c}7 \\
(16.3)\end{array}$ & 8 \\
\hline $\begin{array}{l}\text { Gunal } \\
\text { et al. } \\
\text { (2021) }\end{array}$ & Turkey & Caucasian & $\begin{array}{c}\text { Severity } \\
\text { (need of intensive } \\
\text { care) }\end{array}$ & 67 & 16.4 & $\begin{array}{c}19 \\
(63.3)\end{array}$ & $\begin{array}{c}40 \\
(66.67)\end{array}$ & $\begin{array}{c}22 \\
(73.3)\end{array}$ & $\begin{array}{c}18 \\
(30)\end{array}$ & $\begin{array}{c}12 \\
(12)\end{array}$ & $\begin{array}{c}3 \\
(5)\end{array}$ & 6 \\
\hline
\end{tabular}

CBS - Clark-Baudouin scale; NR - not reported 
Table 2. Hardy-Weinberg Equilibrium (HWE) for included studies

\begin{tabular}{|l|c|c|c|c|c|c|c|}
\hline \multirow{2}{*}{ Author } & \multicolumn{3}{|c|}{ Severe group } & \multicolumn{3}{c|}{ Non-severe group } & \multirow{2}{*}{ HWE } \\
\cline { 2 - 8 } & DD & ID & II & DD & ID & II & \\
\hline Gómez et. al. (2021) & 31 & 31 & 5 & 44 & 76 & 17 & 0.211 \\
\hline Celik et al. (2021) & 24 & 42 & 10 & 24 & 37 & 17 & 0.65 \\
\hline Verma et al. (2020) & 30 & 48 & 42 & 17 & 58 & 74 & 0.118 \\
\hline Calabrese et al. (2021) & 18 & 4 & 3 & 20 & 21 & 2 & 0.703 \\
\hline Gunal et al. (2021) & 19 & 2 & 9 & 26 & 12 & 22 & $>0.05$ \\
\hline
\end{tabular}

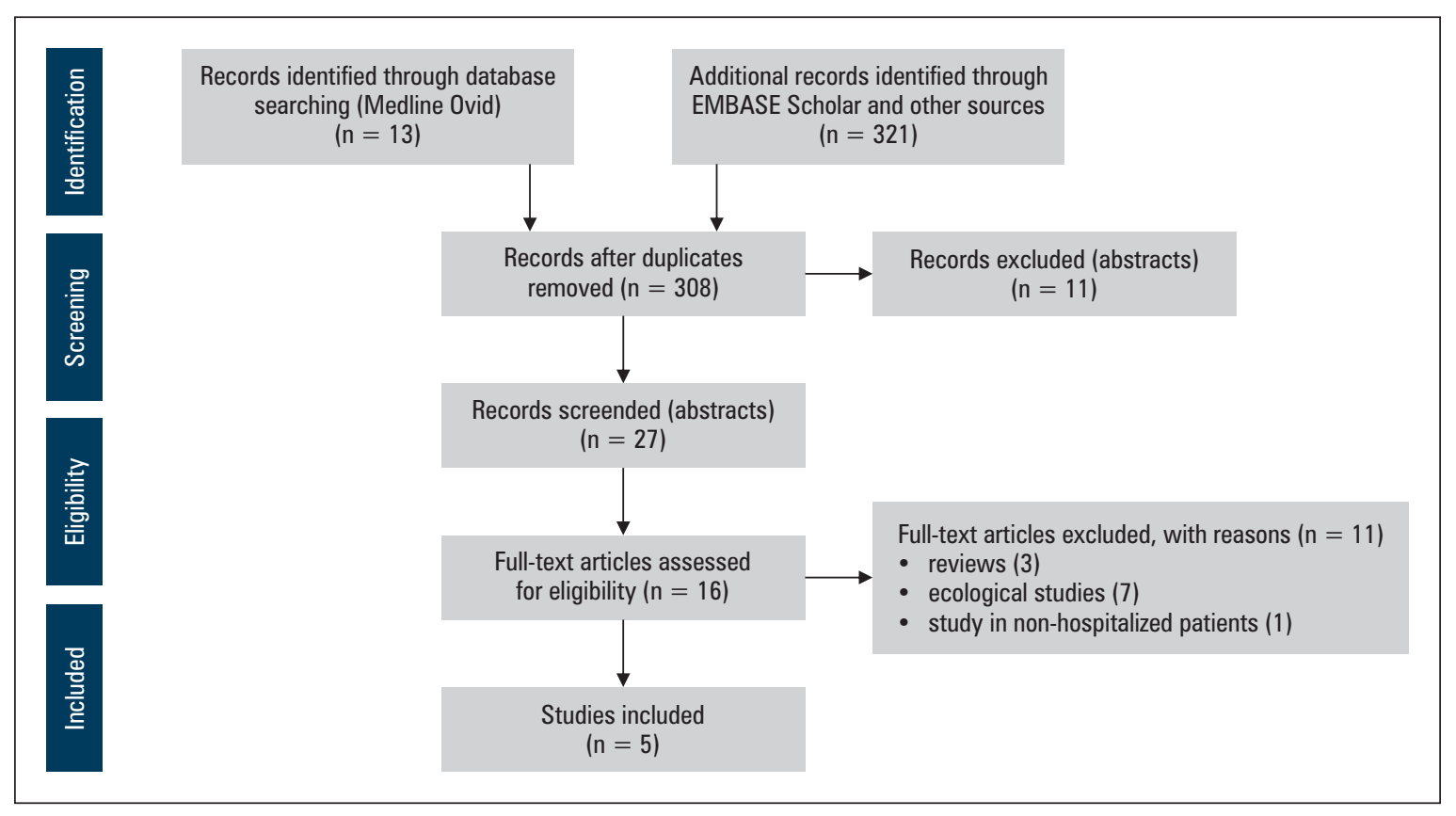

Figure 1. Flowchart of included studies

However, results should be viewed with caution because this is only based on 5 observational studies, 4 of which were conducted in Caucasians and none of which included mortality as outcome.

Even though the present study is the first meta-analysis on $A C E I / D$ polymorphism and severity of SARS-CoV-2 infection in hospitalized patients, it is possible to compare it with other meta-analyses on ACE genotype and risk of severity and mortality due to acute lung injury (ALI)/acute respiratory distress syndrome (ARDS), published before the COVID-19 pandemic. Matsuda et al. found a possible association between the DD polymorphism and the mortality risk of ALI/ARDS [22]. Hu et al. [23] found that Caucasian patients with ARDS had a significantly higher frequency of the DD genotype (OR: 1.65; 95\% CI: 1.27-2.13) than controls. The meta-analysis of Pabalan et al. published in 2021 found a significant association between DD ( $v$ s. II + ID) and a higher risk of mortality due to ALI/ARDS in Caucasians and children as well as in Asians [24].

On the other hand, prior to the COVID-19 pandemic, association studies between the ACE genotype and arterial hypertension and type 2 diabetes mellitus were published. A meta-analysis found an association between the $\mathrm{D}$ allele and essential hypertension in Asian and Caucasian population [25]. Another meta-analysis found that the $\mathrm{D}$ variant was associated with a $14 \%$ increased risk of type 2 diabetes mellitus relative to the I variant, in Caucasian and East Asians [26]. And another meta-analysis found an association between the $\mathrm{D}$ allele and the risk of essential hypertension compared to the carriers of the I allele in the African continent [27].

In the pathophysiology of COVID-19, the counterbalance between angiotensin converting enzyme (ACE) and ACE2 activities may play a role potential- 


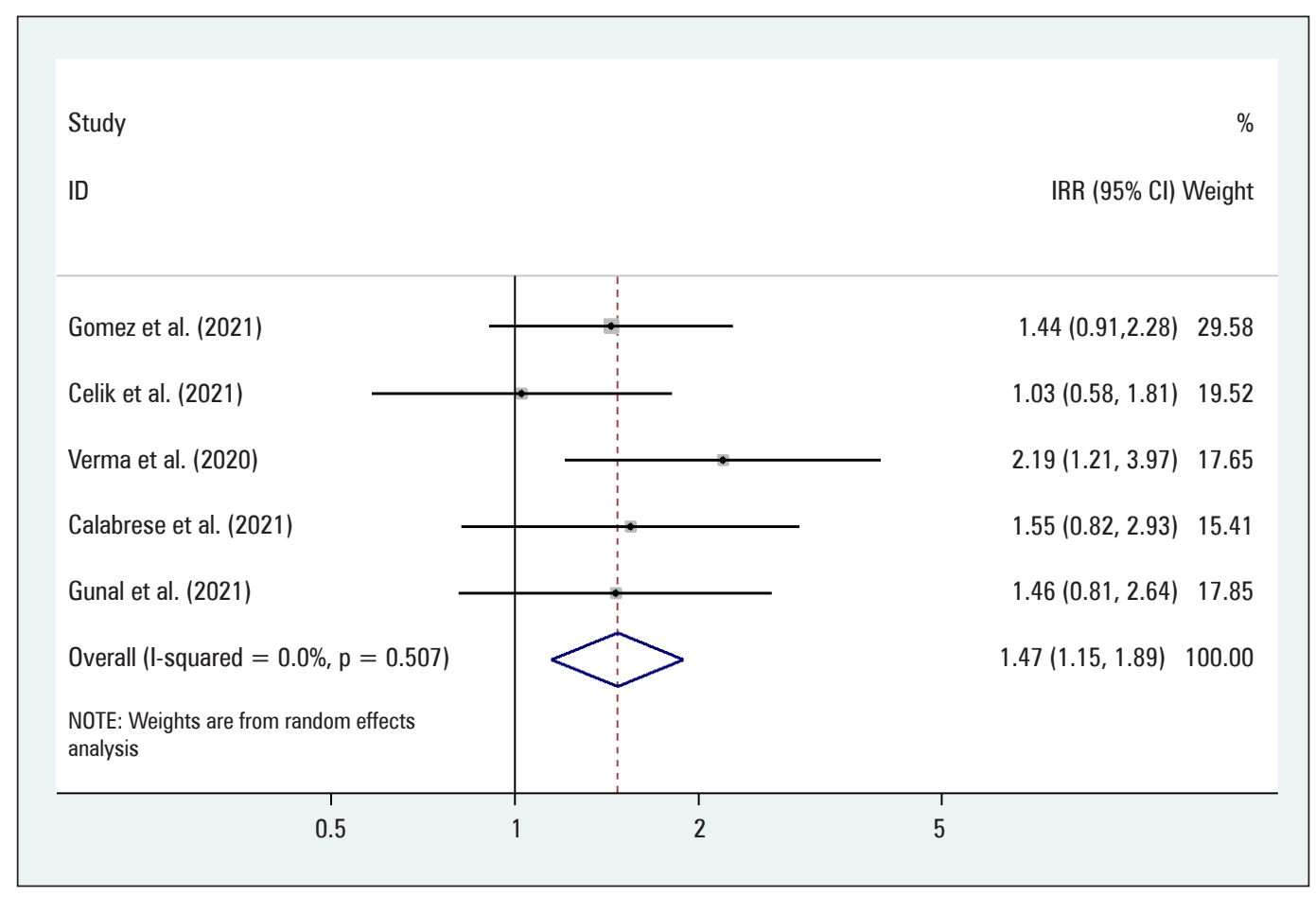

Figure 2. Forest plot for the effect of $A C E I / D$ gene polymorphism on the association of severity of $S A R S$-CoV-2 infection in hospitalized patients (DD vs. II + ID model)

ly determining the severity of the disease [19, 28-30]. However, putting the issue in context, the ACE gene is actually one of more than 30 SARS-CoV-2 susceptibility gene variants or haplotypes under investigation [31]. A recently genome-wide association analysis identified a 3 p21.31 gene cluster as a genetic susceptibility locus in patients with Covid-19 with respiratory failure and confirmed a potential involvement of the $\mathrm{ABO}$ blood-group system [32]. Another study found significant associations with chromosome $12 \mathrm{q} 24.13$ in a gene cluster that encodes antiviral restriction enzyme activators $(O A S 1, O A S 2$ and OAS3); chromosome 19p13.2 near the gene that encodes tyrosine kinase 2 (TYK2); chromosome $19 \mathrm{p} 13.3$ within the gene that encodes dipeptidyl peptidase 9 (DPP9); and chromosome 21q22.1 in the interferon receptor gene IFNAR2 [33]. The present study has limitations, especially due to the few published studies and most of them only in Caucasians. Similarly, the design of the included studies compares hospitalized patients and does not include non-hospitalized controls, nor does it analyze mortality. On the other hand, it would be important to study if the ACE gene influences the severity in patients without diabetes or arterial hypertension, and none of the included studies analyzed this group without these risk factors. It would also be important to study whether these results can be replicated in other ethnic groups. It should be noted that the relationship between hypertension and the ACE gene has not been found in studies in Latin American countries such as Peru [34] or Brazil [35].

In conclusion, with the limited studies evaluated predominantly in Caucasians, it appears that the ACE DD genotype may confer a greater risk of severe COVID-19 in hospitalized patients. Further studies at a global level including more diverse ethnic groups are necessary to fully establish this association.

None declared.

\section{Funding}

None declared.

\section{Conflict of interest}

\section{References}

1. Kurdi M, De Mello WC, Booz GW. Working outside the system: an update on the unconventional behavior of the reninangiotensin system components. Int J Biochem Cell Biol. 2005; 37(7): 1357-1367, doi: 10.1016/j.biocel.2005.01.012, indexed in Pubmed: 15833268.

2. Gemmati D, Bramanti B, Serino ML, et al. COVID-19 and Individual Genetic Susceptibility/Receptivity: Role of ACE1/ACE2 Genes, Immunity, Inflammation and Coagulation. Might the Double X-chromosome in Females Be Protective against SARSCoV-2 Compared to the Single X-Chromosome in Males? Int J Mol Sci. 2020; 21(10), doi: 10.3390/ijms21103474, indexed in Pubmed: 32423094. 
3. Gemmati D, Tisato V. Genetic Hypothesis and Pharmacogenetics Side of Renin-Angiotensin-System in COVID-19. Genes (Basel). 2020; 11(9), doi: 10.3390/genes11091044, indexed in Pubmed: 32899439.

4. Hoffmann M, Kleine-Weber H, Schroeder S, et al. SARS-CoV-2 Cell Entry Depends on ACE2 and TMPRSS2 and Is Blocked by a Clinically Proven Protease Inhibitor. Cell. 2020; 181(2): 271-280.e8, doi: 10.1016/j.cell.2020.02.052, indexed in Pubmed: 32142651

5. Gheblawi M, Wang K, Viveiros A, et al. Angiotensin-Converting Enzyme 2: SARS-CoV-2 Receptor and Regulator of the ReninAngiotensin System: Celebrating the 20th Anniversary of the Discovery of ACE2. Circ Res. 2020; 126(10): 1456-1474, doi: 10.1161/CIRCRESAHA.120.317015, indexed in Pubmed: 32264791

6. Imai Y, Kuba K, Rao S, et al. Angiotensin-converting enzyme 2 protects from severe acute lung failure. Nature. 2005; 436(7047): 112-116, doi: 10.1038/nature03712, indexed in Pubmed: 16001071

7. Itoyama $\mathrm{S}$, Keicho $\mathrm{N}$, Quy T, et al. ACE1 polymorphism and progression of SARS. Biochem Biophys Res Commun. 2004; 323(3): 1124-1129, doi: 10.1016/j.bbrc.2004.08.208, indexed in Pubmed: 15381116.

8. Bellone M, Calvisi SL. ACE polymorphisms and COVID-19related mortality in Europe. J Mol Med (Berl). 2020; 98(11): 1505-1509, doi: 10.1007/s00109-020-01981-0, indexed in Pubmed: 32935155.

9. Aung ArK, Aitken T, Teh BM, et al. Angiotensin converting enzyme genotypes and mortality from COVID-19: An ecological study. J Infect. 2020; 81(6): 961-965, doi: 10.1016/j. jinf.2020.11.012, indexed in Pubmed: 33197472

10. Pati A, Mahto H, Padhi S, et al. ACE deletion allele is associated with susceptibility to SARS-CoV-2 infection and mortality rate: An epidemiological study in the Asian population. Clin Chim Acta. 2020; 510: 455-458, doi: 10.1016/j.cca.2020.08.008, indexed in Pubmed: 32791137.

11. Yamamoto N, Ariumi Y, Nishida N, et al. SARS-CoV-2 infections and COVID-19 mortalities strongly correlate with ACE1 I/D genotype. Gene. 2020; 758: 144944, doi: 10.1016/j. gene.2020.144944, indexed in Pubmed: 32628976.

12. Delanghe JR, Speeckaert MM, De Buyzere ML. The host's angiotensin-converting enzyme polymorphism may explain epidemiological findings in COVID-19 infections. Clin Chim Acta. 2020; 505: 192-193, doi: 10.1016/j.cca.2020.03.031, indexed in Pubmed: 32220422.

13. Moher D, Liberati A, Tetzlaff J, et al. PRISMA Group. Preferred reporting items for systematic reviews and meta-analyses: the PRISMA statement. Int J Surg. 2010; 8(5): 336-341, doi: 10.1016/j.ijsu.2010.02.007, indexed in Pubmed: 20171303.

14. Ghasemi A, Zahediasl S. Normality tests for statistical analysis: a guide for non-statisticians. Int J Endocrinol Metab. 2012; 10(2): 486-489, doi: $10.5812 / \mathrm{ijem} .3505$, indexed in Pubmed: 23843808.

15. Clark MF, Baudouin SV. A systematic review of the quality of genetic association studies in human sepsis. Intensive Care Med. 2006; 32(11): 1706-1712, doi: 10.1007/s00134-006-0327-y, indexed in Pubmed: 16957907.

16. DerSimonian R, Laird N. Meta-analysis in clinical trials. Control Clin Trials. 1986; 7(3): 177-188, doi: 10.1016/01972456(86)90046-2, indexed in Pubmed: 3802833.

17. Gómez J, Albaiceta GM, García-Clemente M, et al. Angiotensin-converting enzymes (ACE, ACE2) gene variants and COVID-19 outcome. Gene. 2020; 762: 145102, doi: 10.1016/j. gene.2020.145102, indexed in Pubmed: 32882331.

18. Verma $S$, Abbas M, Verma $S$, et al. Impact of I/D polymorphism of angiotensin-converting enzyme 1 (ACE1) gene on the severity of COVID-19 patients. Infect Genet Evol. 2021; 91: 104801, doi: $10.1016 /$ j.meegid.2021.104801, indexed in Pubmed: 33676010 .
19. Calabrese C, Annunziata A, Coppola A, et al. ACE Gene I/D Polymorphism and Acute Pulmonary Embolism in COVID19 Pneumonia: A Potential Predisposing Role. Front Med (Lausanne). 2020; 7: 631148, doi: 10.3389/fmed.2020.631148, indexed in Pubmed: 33585520.

20. Çelik SK, Genç CÇ, Piskin N, et al. ACE I/D and ACE2 receptor gene (RS2106809, RS2285666) polymorphisms is not related to the clinical course of COVID-19; a case study. Authorea Preprints. 2021, doi: 10.22541/au.161572992.20220722/v1.

21. Gunal O, Sezer O, Ustun GU, et al. Angiotensin-converting enzyme-1 gene insertion/deletion polymorphism may be associated with COVID-19 clinical severity: a prospective cohort study. Ann Saudi Med. 2021; 41(3): 141-146, doi: 10.5144/02564947.2021.141, indexed in Pubmed: 34085542.

22. Matsuda A, Kishi T, Jacob A, et al. Association between insertion/ deletion polymorphism in angiotensin-converting enzyme gene and acute lung injury/acute respiratory distress syndrome: a metaanalysis. BMC Med Genet. 2012; 13: 76, doi: 10.1186/14712350-13-76, indexed in Pubmed: 22938636.

23. Hu Z, Jin X, Kang Y, et al. Angiotensin-converting enzyme insertion/deletion polymorphism associated with acute respiratory distress syndrome among caucasians. J Int Med Res. 2010; 38(2): 415-422, doi: 10.1177/147323001003800204, indexed in Pubmed: 20515555.

24. Pabalan N, Tharabenjasin P, Suntornsaratoon P, et al. Ethnic and age-specific acute lung injury/acute respiratory distress syndrome risk associated with angiotensin-converting enzyme insertion/ deletion polymorphisms, implications for COVID-19: A metaanalysis. Infect Genet Evol. 2021; 88: 104682, doi: 10.1016/j. meegid.2020.104682, indexed in Pubmed: 33338639.

25. Liu M, Yi J, Tang W. Association between angiotensin converting enzyme gene polymorphism and essential hypertension: A systematic review and meta-analysis. J Renin Angiotensin Aldosterone Syst. 2021; 22(1): 1470320321995074 , doi: $10.1177 / 1470320321995074$, indexed in Pubmed: 33726555.

26. Zhou JB, Yang JK, Lu JK, et al. Angiotensin-converting enzyme gene polymorphism is associated with type 2 diabetes: a meta-analysis. Mol Biol Rep. 2010; 37(1): 67-73, doi: 10.1007/ s11033-009-9648-6, indexed in Pubmed: 19655271.

27. Mengesha HG, Petrucka P, Spence C, et al. Effects of angiotensin converting enzyme gene polymorphism on hypertension in Africa: A meta-analysis and systematic review. PLoS One. 2019; 14(2): e0211054, doi: 10.1371/journal.pone.0211054, indexed in Pubmed: 30763326.

28. Li M, Schifanella L, Larsen PA. Alu retrotransposons and COVID-19 susceptibility and morbidity. Hum Genomics. 2021; 15(1): 2, doi: 10.1186/s40246-020-00299-9, indexed in Pubmed: 33390179.

29. McFadyen JD, Stevens H, Peter K. The Emerging Threat of (Micro) Thrombosis in COVID-19 and Its Therapeutic Implications. Circ Res. 2020; 127(4): 571-587, doi: 10.1161/CIRCRESAHA.120.317447, indexed in Pubmed: 32586214.

30. Verdecchia P, Cavallini C, Spanevello A, et al. The pivotal link between ACE2 deficiency and SARS-CoV-2 infection. Eur J Intern Med. 2020; 76: 14-20, doi: 10.1016/j.jejim.2020.04.037, indexed in Pubmed: 32336612.

31. Novelli G, Biancolella M, Mehrian-Shai R, et al. COVID-19 one year into the pandemic: from genetics and genomics to therapy, vaccination, and policy. Hum Genomics. 2021; 15(1): 27, doi: 10.1186/s40246-021-00326-3, indexed in Pubmed: 33966626.

32. Severe Covid-19 GWAS Group. Genomewide Association Study of Severe Covid-19 with Respiratory Failure. N Engl J Med. 2020; 383(16): 1522-1534, doi: 10.1056/nejmoa2020283, indexed in Pubmed: 32558485.

33. Pairo-Castineira E, Clohisey S, Klaric L, et al. GenOMICC Investigators, ISARIC4C Investigators, COVID-19 Human Genetics Initiative, 23andMe Investigators, BRACOVID Investigators, Gen-COVID Investigators. Genetic mechanisms of critical illness 
in COVID-19. Nature. 2021; 591 (7848): 92-98, doi: 10.1038/ s41586-020-03065-y, indexed in Pubmed: 33307546.

34. Oscanoa T, Cieza E, Lizaraso-Soto F, et al. Lack of association between angiotensin-converting enzyme (ACE) genotype and essential hypertension in Peruvian older people. Arterial Hypertension. 2020; 24(3): 115-119, doi: 10.5603/ah.a2020.0011.
35. Bonfim-Silva R, Guimarães LO, Souza Santos J, et al. Case-control association study of polymorphisms in the angiotensinogen and angiotensin-converting enzyme genes and coronary artery disease and systemic artery hypertension in African-Brazilians and Caucasian-Brazilians. J Genet. 2016; 95(1): 63-69, doi: $10.1007 /$ s12041-015-0599-5, indexed in Pubmed: 27019433. 